\title{
Critical action research in human resource development
}

Rod P. Githens

University of the Pacific, rgithens@pacific.edu

Follow this and additional works at: https://scholarlycommons.pacific.edu/ed-facpres

Part of the Education Commons

\section{Recommended Citation}

Githens, Rod P., "Critical action research in human resource development" (2007). Benerd School of Education Faculty Presentations. 280.

https://scholarlycommons.pacific.edu/ed-facpres/280 


\title{
Critical Action Research in Human Resource Development
}

\author{
Rod P. Githens \\ University of Illinois at Urbana-Champaign
}

Critical approaches to HRD do not focus solely on improving organizational performance; instead, they address previously undiscussable issues such as power, politics, class, sexism, racism, and heterosexism. Since critical HRD often seeks to raise problems instead of solve them immediately, it is sometimes criticized for being elitist and detached from practice. In this paper, I propose that critical approaches to action research can allow practitioners and researchers to integrate critical approaches into actual practice.

Keywords: Critical HRD, Action Research, Methodology

Critical human resource development (HRD) is receiving increasing attention in the HRD field. The recent influx of critical HRD has come largely from those with European HRD perspectives (e.g., Elliott \& Turnbull, 2005a) and from those with a background in North American adult education. However, North American HRD researchers are also recognizing the benefits of applying critical perspectives to HRD (e.g., Hatcher, 2006a; Hatcher, 2006b). Critical perspectives encompass a broad set of issues that include examinations of power, politics, ideology, and status (Fenwick, 2004; Trehan, 2004). Bierema and Cseh (2003) concluded that issues of power, politics, sexism, racism, and homophobia are "undiscussable" within the Academy of HRD (AHRD), based on a comprehensive review of AHRD conference papers. These undiscussable issues have real consequences for individuals and organizations. In other words, examination of HRD issues from critical perspectives is not an elitist exercise. However, critical theory seeks to "problematize" rather than solve problems; therefore, it has been criticized for emphasizing problem identification rather than practical applications (Valentin, 2006). One solution to this dilemma is to ensure that critical HRD researchers maintain close relationships with practitioners and organizations. Without these symbiotic relationships, researchers are at risk of becoming elitist, which could result in an isolated movement that makes no social impact and fails to understand the complexity of real organizations (Fenwick, 2004). Additionally, there is a risk of hypocrisy when critical theorists make prescriptive pronouncements about how others should improve the world (Fenwick, 2004). I argue that critical action research is a viable way to overcome this risk of becoming elitist. Not only does critical action research help ensure that researchers do not become removed from organizations; it also empowers practitioners to conduct their practice from a critical perspective.

Action research is largely seen within North American HRD as a problem-solving method (Swanson, 1997). In fact, Swanson contends that most researchers do not consider action research to be real research. Others contend that action research is a viable, legitimate form of research for problem solving within organizations, knowledge production for the field, and publication in scholarly outlets (e.g., Brooks \& Watkins, 1994; Marsick \& Watkins, 1997). Brooks and Watkins explain that action research should be more acceptable (for publication) than in the past, due to an increasing openness to specific, local knowledge presented through interpretive and qualitative studies.

In this paper, I will adopt the perspective of Brooks, Marsick, Watkins, and others who see action research as a viable form of research. A strong precedence exists for using action research to address social, political, and power issues within the fields of adult education, teacher education, and community development (Anderson, Herr, \& Nihlen, 1994; Noffke, 1997b). It seems that critical action research is also viable in our field. Adoption of critical action research in HRD will provide attention to larger social issues, while being grounded in practice. This attention to social issues can provide an alternative to the dominant production-focused approaches to HRD.

To make this case, I first present a framework for viewing research within HRD. Next, I synthesize a selection of literature related to critical HRD, drawing on critical perspectives from adult education, organization studies, and HRD. I include the perspectives of major critical and postmodern thinkers outside of education and organization studies. Lastly, I provide a brief historical perspective of action research (and related approaches) within HRD and related fields, followed by an integrated perspective of how critical action research is viable for HRD.

\section{Research in HRD}

Research in HRD can be classified using Burrell and Morgan's (1979) classic model of four research paradigms in organizational studies. The four paradigms are placed in a $2 \times 2$ model with two continuums: subjective-objective and

$$
\text { Copyright (C) } 2007 \text { Rod P. Githens }
$$

In (2007) F. M. Nafukho (Ed.), Academy of Human Resource Development Conference Proceedings. Bowling Green, OH: AHRD. 
sociology of radical change-sociology of regulation. Subjectivity and objectivity are easily understood, as most are familiar with the debate over positivist approaches and interpretive approaches (oftentimes mislabeled as a debate between quantitative and qualitative approaches to research). The sociology of radical change and the sociology of regulation need further explanation, since this debate is not as common in HRD circles. Burrell and Morgan explain that the sociology of regulation emphasizes unity and cohesiveness of societies/organizations since they gravitate toward order. The main concern is with what is. The sociology of radical change focuses on understanding deepseated conflict within societies/organizations since chaos and contradictions are dominating forces. Additionally, it is concerned with changing society through emancipation. In the sociology of radical change, a key difference is the focus on potentiality, rather than only examining actuality. Within these continuums, Burrell and Morgan's four paradigms are: functionalist, interpretive, radical humanist, and radical structuralist (Table 1). It is important to recognize that these four paradigms exist within the continuums. They are not absolute categories with finite boundaries.

Table 1. Research Paradigms (taken from Burrell \& Morgan, 1979)

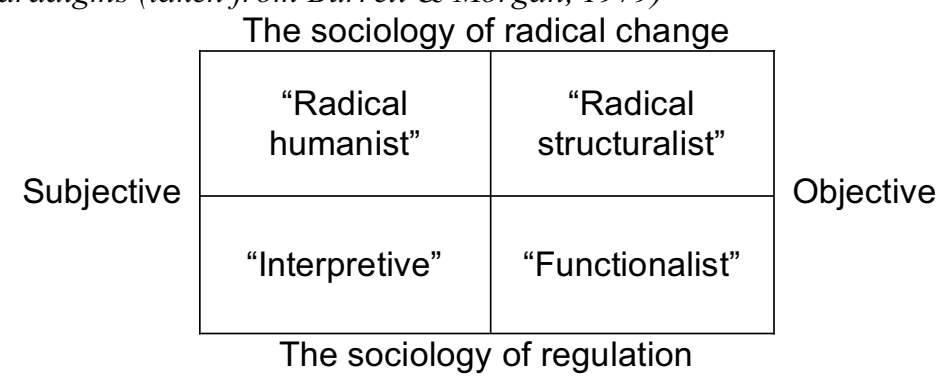

Most research in HRD exists within the functionalist paradigm, which aims for objectivity and regulation or control of the system. This type of research can include both qualitative and quantitative research that seeks to explain problems and phenomena. Work within this paradigm is usually conducted so that it can affect policies and practices through social engineering (Burrell \& Morgan, 1979) or technocratic approaches to problems. Oftentimes, this means that top-down approaches are taken, in which large-scale changes are made within organizations.

The second most common paradigm in HRD is the interpretive paradigm, which recognizes subjectivity while implicitly adopting the perspective of the sociology of regulation (especially in its emphasis on understanding the status quo versus making changes to deep-seated problems). Interpretive researchers seek a deep understanding of local settings and are not usually concerned with making direct inferences to larger systems (Burrell \& Morgan, 1979).

Radical humanism recognizes subjectivity, while seeking radical change. A main emphasis for radical humanism is in the seeking of potentiality, through transcending existing forms of domination (Burrell \& Morgan, 1979). Most critical approaches fall within this paradigm, which is heavily influenced by the early writings of Marx and members of the Frankfurt school of critical theory. Radical humanism emphasizes small-scale, local changes and rejects social engineering. In most ways, this approach is antithetical to the functionalist approach seen in most HRD research.

On the other hand, radical structuralism advocates objective approaches to making radical changes. Its approach to science is similar to functionalism, but the goals are fundamentally different. Like radical humanism, radical structuralism seeks to critique society and organizations, but it focuses on large-scale structural relationships. Radical structuralism is the least common approach to HRD research, with its most influential theorists being Marx (his later work), Engels, and Lenin (Burrell \& Morgan, 1979).

\section{What is Critical HRD?}

Those working within critical HRD are influenced by theories ranging from postmodernism to postcolonialism to theories originating with the Frankfurt school (Elliott \& Turnbull, 2005b). Although the theories are quite diverse, the uniting factor is a "common concern to question HRD's 'taken-for-granteds"” (Elliott \& Turnbull, 2005b, p. 2). Additionally, critical HRD perspectives do not focus solely on improving organizational performance. Most perspectives within critical HRD fall in the "radical humanism" paradigm.

As mentioned earlier, critical issues have not been addressed frequently in HRD research. Bierema and Cseh (2003) analyzed over 600 papers presented at the North American AHRD conferences from 1996 to 2000. They 
found that issues of power were addressed in only four percent of the papers. They conclude that HRD research sometimes uses gender or other diversity categories as units of analysis, but most research fails to address "issues of social justice in the workplace or [the] larger social context" (p. 23). "Undiscussable" issues such as "sexism, racism, patriarchy, and violence receive little attention in the literature yet have considerable impact on organizational dynamics" (pp. 23-24). Again, examination of issues through critical perspectives is not inherently elitist due to the major impact that these issues have on people and organizations.

Although critical issues have largely been unconsidered, HRD does sometimes include "student-centered aspirations for social equality," (Trehan, 2004, p. 30) based on humanistic ideals. However, these humanistic perspectives have included little discussion of power, politics, or larger social forces. Interestingly, softer forms of humanism have been espoused as being an integral part of HRD by those advocating both learning-oriented perspectives and performance-oriented perspectives (e.g., Swanson \& Holton, 2001). McGuire, Cross, and O'Donnell (2005) contend that a more honest and ethical approach is needed. According to their perspective, HRD (especially in for-profit corporations) is almost always used for the ultimate purpose of profit (also see Kuchinke, 1999). Instead of acknowledging this fact, many people espouse a unitary perspective in which employees are encouraged to believe that their interests are wholly aligned with the interests of the corporation (also see Ciulla, 2000). Obviously, management and worker interests are not always aligned. Instead, a more complex and forthcoming perspective is needed where various interests are acknowledged. In many workplaces, it is politically incorrect to openly discuss issues of workplace politics or power. When workplace politics are discussed, the term "politics" is often used as a pejorative, in labeling the actions of another department or person. Self-reflexive discussions of power and politics can help us understand our own uses of power. Rejecting a unitary perspective and discussing power and politics does not mean that people will or should conclude that managers are evil and workers are pure. Instead, an open acknowledgement that these issues are real can help to foster more open communication (i.e., communication that is not forced to occur under illusions of egalitarianism and unified interests).

As an example of the reluctance to discuss controversial topics, Hanscome and Cervero (2003) found that men were especially reluctant to admit that gender plays a role in power relations, while females were much more forthcoming in discussing the role of gender in power relations at work. They also found that men preferred to speak in impersonal terms when discussing how gender affects power relations in their own work lives. On the other hand, women were direct in talking about how these issues have affected them personally. We often avoid discussing power and politics in organizations, because power is seen as being wholly negative and oppressive. As Foucault (1978) argued, power is complex and multifaceted. It is not merely wielded by those in official positions of authority, but is dynamic, changing, and exercised from multiple and changing perspectives. The exercise of power can be used for achieving positive societal changes. Discussing power allows us to deconstruct our assumptions about the everyday practices we engage in (Trehan, 2004). The examination of power does not necessarily mean describing oppression by others; it is also self-reflexive in helping us to look at the ways in which we exercise power as researchers and practitioners.

Trehan (2004) contends that HRD education has not prepared HRD practitioners to address these wider issues of power and responsibility. Instead, most HRD education has been apolitical and assumes that HRD is neutral. Addressing these issues within HRD academic programs is one way to put these issues into the open, which I will discuss later.

\section{Critical HRD's Levels of Intensity}

"Critical reflection" has a wide variety of meanings in workplaces (Brookfield, 2000). Most commonly, this label describes challenges to the status quo, which help individuals and groups develop completely new paradigms for solving problems (e.g., double-loop learning, examining internal politics) (e.g., Vince, 2003). Put another way, a critical perspective is associated with "challenging practices, exposing assumptions, revealing illusions and questioning tradition. Being critical means recognizing...messiness, complexities, and irrationality..." (Sambrook, 2004, p. 614). Second, "critical reflection" is also used to describe challenges to an organization's way of doing business (e.g., challenging labor practices or environmental degradation), which includes a critique of capitalism as we now know it. Lastly, much less common is the use of critical reflection in calling for an overthrow of the entire system (e.g., transforming capitalist systems into something different). All of these degrees of critical reflection can result in positive societal changes, but they vary in their intensity and scope. Fenwick (2004) presents an argument for focusing on "small wins" within local settings, recognizing both the strength of "acting locally" and the pragmatic need to focus on small critical projects in order to minimize risk for the practitioners engaging in them. Critical HRD in most for-profit companies will likely focus on the first two types of critical reflection and action. In 
other words, we are unlikely to see attempts to overthrow capitalism from those working in for-profit companies since most employees (at all levels) are not willing to risk losing their jobs. Meyerson and Scully (1995) coined the term "tempered radical" to describe individuals who are deeply committed to making social change within organizations but are tempered because of an acknowledgement that smaller-scale changes are more feasible within their organizations. However, within non-profit advocacy groups, critical perspectives could be used in larger-scale ways. Whatever the level of intensity, action research has the potential of being a valuable approach in adopting a critical perspective.

\section{What is Action Research?}

The term "action research" is contested and has various meanings in different settings. Additionally, several related terms overlap in some ways (e.g., participatory research, participatory action research, practitioner research, action science). Approaches to action research could be placed in each of Burrell and Morgan's four paradigms. In fact, the primary differences between action research approaches are easiest to understand by using a rubric such as that presented by Burrell and Morgan. Before presenting my understanding of action research, I will present a short background on its history.

Action research has a long and complicated history. In this space, I can only provide a cursory overview, which should help put some perspective on the emergence of action research (for more detailed accounts, see Noffke, 1994, 1997b). John Collier, the Commissioner of Indian Affairs for the U.S. government from 1933-1945 is widely seen as one of the early advocates for action research in the U.S. (Noffke, 1997b). Collier believed that Native American communities should see tangible benefits from research, rather than being subjected to social research that merely sought to understand their culture. However, Kurt Lewin, a Jewish refugee who came to the U.S. during World War II, is largely seen as providing action research with its theoretical footing (Anderson et al., 1994; Brooks \& Watkins, 1994; Noffke, 1994). Lewin sought to institute changes and understand the effects of those changes. He integrated social theory and action. Rather than merely focusing on solving problems, he was deeply concerned with contributing to the wider community of knowledge through his work. Lewin's work included examinations of social problems (e.g., addressing discrimination issues) as well as industrial issues (e.g., improving efficiency) (Noffke, 1997a). Another influence in action research is seen through the work of John Dewey, who greatly influenced early action researchers through his rejection of the separation of research and practice. He warned against borrowing experimental methods from the natural sciences and advocated for approaches that were similar to action research (Noffke, 1997b). However, by the late 1950s, action research greatly declined in the U.S., due to the dominance of the positivist paradigm (i.e., functionalism) and its emphasis on generalizability (Anderson et al., 1994). In other words, action research was not seen as being legitimate research since it could not be directly generalized to larger populations.

In the U.S., action research continued mainly as a problem solving technique within organizations and schools. The earlier approaches of Collier and Lewin, which emphasized examinations of social issues, were now transformed into largely apolitical activities (Noffke, 1994). In HRD, action research continues to be seen as an organization development (OD) tool that is primarily centered around the role of the OD/HRD consultant (Cummings \& Worley, 2005; Kemmis \& McTaggart, 2000; Maurer, 2006) (for a discussion about action science, which is closely related to action research, see Argyris \& Schön, 1991). Most perceptions of action research within HRD and organizational studies place it primarily within the functionalist paradigm. However, there are exceptions. William Foote Whyte (e.g., 1991) worked for decades in the area of participatory action research (PAR). Whyte's form of PAR was largely centered around a democratic sociocultural approach (Brooks \& Watkins, 1994). Similarly, Eric Trist worked from a democratic sociotechnical approach for most of his life, until he died in 1993 (see Trist, 1993). Currently, approaches such as appreciative inquiry, dialogue conferences, and storytelling conferences emphasize the transformative effects of dialogue in action research (Maurer, 2006). These approaches are increasingly becoming more popular within organizations and have the potential of moving further away from the functionalist paradigm. However, approaches like these emphasize widespread participation, but not an examination of deeper social problems. For that reason, work like this is better classified as humanistic than critical (Kemmis \& McTaggart, 2000). In other words, this work seeks milder humanistic aims, but does not seek to understand the underlying sources of social problems. Another continuing stream of PAR is seen in adult education, particularly with the work of Paulo Freire, the Brazilian adult educator (starting in the 1960s). Freire's literacy education work among poor Brazilians aimed to help students conduct their own research, which resulted in social action and the questioning of societal norms and injustices (Anderson et al., 1994). In the U.S., the community development work of the Highlander Center in Tennessee is widely used as an example of PAR (e.g., see Merrifield, 1997). Highlander heavily advocates critical approaches in its work with rural communities in Appalachia. 
In the UK and Australia, action research did not fall out of favor as it did in the U.S (Anderson et al., 1994). In fact, there are strong traditions of action research in education, management, and community development both inside and outside of academia. In the U.S., the last twenty years has seen a resurgence of action research in K-12 education (often called "teacher research" or "practitioner research") (Anderson et al., 1994; Cochran-Smith \& Donnell, 2006). Much of this work is centered around teachers doing their own research in collaborative groups, which is oftentimes disseminated to larger audiences through conferences and publications. University researchers are sometimes affiliated with these groups. Action research has also become respectable in some U.S. management programs in universities (e.g., Case Western Reserve University, Massachusetts Institute of Technology). With these developments, action research that is conducted by practitioners and university researchers is being presented at national conferences, published in respectable academic journals, and published in journals centered around action research (e.g., Action Research, Educational Action Research, Systemic Practice and Action Research).

After presenting this brief historical overview, I should outline my perspective on action research. However, I will avoid a concise and simplistic definition. A common way to describe action research is that it is a loose set of principles used in everyday practice to (a) understand what has happened in the past, (b) plan for future actions, (c) implement those actions, and (d) reflect on those actions after they have occurred. These steps are typically conceptualized as occurring in multiple cycles or spirals. Most action researchers acknowledge that these steps and cycles often overlap. They are not always neat and tidy. Although there is some general agreement on those ideas, there are vastly different perspectives on other aspects of action research. Some forms of action research rely heavily on theory and formal data collection; others do not. Action research can consider larger social issues and attempt to change the status quo; other approaches seek to make changes within the existing system. At its heart, action research is about deep involvement and action by the people being studied. Sometimes this means that the people being studied are the people doing the action research. Other times it means that an outside consultant is used. Action research can seek small-scale localized changes or it can seek large-scale changes. Some action researchers reject the idea of top-down change, while others embrace ideas of social engineering. These contrasts highlight how present-day applications of action research are implemented for vastly different aims and goals, as outlined in Burrell and Morgan's four paradigms. Many of these differences can be traced back to the various philosophical roots of action research. Action research, like research in general, needs to be understood in terms of its philosophical underpinnings.

\section{How Does Action Research Relate to Critical HRD?}

As I outlined above, action research can be used for a variety of purposes and can be used in vastly different ways. However, I argue that the critical use of action research is one of its most powerful applications due to its emphasis on integrating research and practice to seek social change. Similarly, using action research is one of the most vital ways for critical HRD to make a difference. These ideas are supported by the ancient ideas of Aristotle and the more modern thinking of Habermas.

Aristotle described three types of knowledge: episteme, techne, and phronesis knowledge. Most social science research focuses on episteme knowledge (i.e., predictive, theoretical knowledge), which is combined with techne knowledge (i.e., practical technical knowledge) (Flyvbjerg, 2001). Habermas, an influential member of the Frankfurt School of critical theory, believed strongly in Aristotle's concept of phronesis, which integrates practical and moral knowledge (Flyvbjerg, 2001). In other words, Habermas advocated inquiry that does not neglect the practical day-to-day concerns, but integrates those practical concerns with larger moral and societal issues. Additionally, Habermas rejected the linear notion that theory should drive practice. Instead, he advocated the integration of theory into the everyday lives of practitioners (McNiff, 2000). Action research is a natural fit with Habermas' ideas of critical theory and has long been used for emancipatory purposes and community action (Trehan $\&$ Rigg, 2003). The principles behind critical action research have a long history beyond the functionalist problem solving methods that we often see in HRD action research. Functionalist approaches to action research surely have a place in our field, but critical approaches also provide an opportunity to utilize Aristotle's ideas of phronesis by integrating moral and societal issues with everyday practical concerns.

As I mentioned earlier, critical HRD seeks to "problematize" rather than solve problems; however, it has been criticized for placing too much emphasis on alternative explanations and not enough on practical applications (Valentin, 2006). Critical action research emphasizes "problematizing," but encourages some type of action. This action is oftentimes very small scale and cannot necessarily be used as a replicable model for others to follow. However, when shared with others, the insights gained through critical action research can provide HRD practitioners with insights into critical questions that are integrated into everyday practice. Some may question whether practitioners would set out to examine critical issues. Some employees $d o$ start critical projects within their 
organizations (e.g., Scully \& Segal, 2002). However, critical action research projects often start as apolitical problem solving efforts, but evolve into efforts that examine larger social and political concerns (Anderson et al., 1994; Herr, 1999; Hinsdale, Lewis, \& Waller, 1995). For example, a project may begin by looking at employee retention issues, but ends in an examination of racial dynamics within the organization. However, many practitioners have little knowledge that critical concepts can be integrated into the practices of HRD. It is important for practitioners to have the knowledge that these issues can be examined from critical perspectives, when necessary.

\section{Individual, Group, and Large-Scale Action Research}

As most types of social research, action research occurs at the individual, group, and organization/large-scale levels. Reason and Bradbury (2001) conclude that action research is most beneficial when it occurs at all three levels. Action research may begin as an individual project and evolve into a small group effort, which could lead to an organization-wide effort. Alternatively, it could begin as a small group effort or a large-scale effort. On the other hand, others are wary of moving beyond the individual or group levels, for fear that action research will become another tool for social engineering (Anderson et al., 1994). There is a fear that organization sponsorship or cooption of action research dilutes its political and emancipatory nature (Cochran-Smith \& Lytle, 1999; Noffke, 1994). Involvement at the large-scale level by an organization could thwart the critical nature of action research, especially within a company or other employing organization. On the other hand, it would be more viable for a critical action research project to be taken to a large-scale level by a labor union or non-profit advocacy group. In such a case, there may be less risk of action research losing its critical edge. However, large-scale projects are often controlled through means of technical rationality, which would certainly go against democratic aims.

HRD can learn from the emerging field of practitioner action research in K-12 education. In these conceptions of action research, it often occurs at the individual or small group levels. The role of university researchers and consultants is oftentimes de-emphasized in favor of grass roots efforts. Individual or small group sponsorship is favored over organization/large-scale projects.

\section{Where Can Critical Action Research be Conducted?}

Trehan and Rigg (2003) explain the need for teaching critical perspectives in university HRD programs. In some ways, the introduction of critical action research into for-profit companies seems most viable among working graduate students who are already employed. There is a strong tradition of critical action research among graduate students in teacher education programs in the U.S. and graduate students of management, HRM, and HRD in the UK (e.g., Corley \& Eades, 2006; Trehan \& Rigg, 2003). Ideally, these critical perspectives will be sustained and spread by the students to other socially conscious employees of the organizations. However, the introduction of critical perspectives to students is not without risk. Depending largely on their level of criticality, students have become alienated from coworkers and managers and have decided to leave organizations as a result of doing critical action research (Corley \& Eades, 2006; Trehan \& Rigg, 2003). Some have endured deep mental and emotional distress as a result of taking critical approaches within organizations (Meyerson \& Scully, 1995). Of course, other projects have had less dramatic personal effects; however, these potential issues should be carefully considered.

Critical action research is also relevant for HRD in an often-overlooked sector: non-profit, volunteer, and advocacy organizations. Although HRD discourse is often centered around for-profit companies, our field has large numbers of practitioners working in the non-profit sector. Within these organizations, HRD is oftentimes intertwined with advocacy and questioning of societal and community norms. Critical action research seems compatible with such efforts. However, we must be cautious in assuming that the internal operations of non-profit and advocacy organizations are idyllic and democratic. Like other organizations, non-profits may have deep-rooted problems or operate in the mold of for-profit enterprises (e.g., English, 2006). These settings could be promising locations for critical action research since one would assume they would be more open to questioning the activities within their own organizations (when compared to for-profit companies). Therefore, critical action research in advocacy and non-profit organizations could examine norms and assumptions both inside and outside of their organizations.

Many advocacy organizations, non-profit organizations, and companies that take strongly humanistic or critical approaches cannot be adequately studied using classic management theories (e.g., Aktouf, 1992). Aktouf provides specific examples of companies in the U.S. and Canada that have rejected a production-centered mindset. In such organizations, critical perspectives are viable for action research within the organizations. In fact, functionalist action research approaches may be inappropriate. Additionally, groups of employee activists within organizations 
are already seeking organizational changes through employee groups focused on issues like gender, race, and sexuality (Scully \& Segal, 2002). Critical approaches to inquiry could be appropriate for many of these groups, as they explore topics such as workplace diversity.

Critical perspectives allow for a more holistic approach that recognizes the multiple dimensions of the human experience, as opposed to solely looking at people as resources to be utilized by the organization. Therefore, critical HRD action research seems most viable in the employing organizations of graduate students, in organizations with critically minded HRD personnel, in non-profit and advocacy groups, and in for-profit enterprises that reject a production-centered mindset.

\section{Conclusion}

Everyone in HRD is concerned with affecting practice, whether we are researchers or practitioners. However, we all have different philosophical orientations toward practice. Some are more concerned with efficiency and production and others are more concerned with fairness and social issues. Some individuals in HRD want to affect top-down changes through research, others want to describe and understand practice, while others want to be actively involved in making small-scale changes or large-scale changes. Critical action research is ideal for those who want to be actively involved in making changes and are concerned with HRD's role in larger societal issues. Like action research, critical action research is not a monolithic concept. There are many conceptions of its use, which are largely based on the location in which it is used and the needs of the stakeholders. As these various approaches are used, it is vital that they are shared with larger communities through discussion groups, presentations, reports, and journal articles. The sharing of experiences will help to influence other practitioners and researchers and help to encourage the growth of critical HRD in actual practice.

\section{References}

Aktouf, O. (1992). Management and theories of organizations in the 1990s: Toward a critical radical humanism? Academy of Management Review, 17(3), 407-431.

Anderson, G. L., Herr, K., \& Nihlen, A. S. (1994). Studying your own school: An educator's guide to qualitative practitioner research. Thousand Oaks, CA: Corwin Press.

Argyris, C., \& Schön, D. A. (1991). Participatory action research and action science compared: A commentary. In W. F. Whyte (Ed.), Participatory action research (pp. 85-96). Newbury Park, CA: Sage.

Bierema, L. L., \& Cseh, M. (2003). Evaluating AHRD research using a feminist research framework. Human Resource Development Quarterly, 14(1), 5-26.

Brookfield, S. (2000). Contesting criticality: Epistemological and practical contradictions in critical reflection. In T. J. Sork, V. Chapman \& R. St. Clair (Eds.), Proceedings of the 41st Annual Adult Education Research Conference (pp. 51-55). Vancouver: University of British Columbia.

Brooks, A., \& Watkins, K. E. (1994). A new era for action technologies: A look at the issues. New Directions for Adult and Continuing Education, 63, 5-16.

Burrell, G., \& Morgan, G. (1979). Sociological paradigms and organisational analysis: Elements of the sociology of corporate life. London: Heinemann.

Ciulla, J. B. (2000). The working life: The promise and betrayal of modern work. New York: Times Books.

Cochran-Smith, M., \& Donnell, K. (2006). Practitioner inquiry: Blurring the boundaries of research and practice. In J. L. Green, G. Camilli \& P. B. Elmore (Eds.), Complementary methods for research in education. Mahwah, NJ: Erlbaum.

Cochran-Smith, M., \& Lytle, S. L. (1999). The teacher research movement: A decade later. Educational Researcher, 28(7), 15-25.

Corley, A., \& Eades, E. (2006). Sustaining critically reflective practitioners: Competing with the dominant discourse. International Journal of Training \& Development, 10(1), 30-40.

Cummings, T. G., \& Worley, C. G. (2005). Organization development and change (8th ed.). Mason, OH: Thomson/South-Western.

Elliott, C., \& Turnbull, S. (2005a). Critical thinking in human resource development. London: Routledge.

Elliott, C., \& Turnbull, S. (2005b). Critical thinking in human resource development: An introduction. In C. Elliott \& S. Turnbull (Eds.), Critical thinking in human resource development. London: Routledge.

English, L. M. (2006). A Foucauldian reading of learning in feminist, nonprofit organizations. Adult Education Quarterly, 56(2), 85-101.

Fenwick, T. J. (2004). Toward a critical HRD in theory and practice. Adult Education Quarterly, 54(3), 193-209. 
Flyvbjerg, B. (2001). Making social science matter: Why social inquiry fails and how it can succeed again. Oxford, UK: Cambridge University Press.

Foucault, M. (1978). The history of sexuality. New York: Pantheon Books.

Hanscome, L., \& Cervero, R. M. (2003). The impact of gendered power relations in HRD. Human Resource Development International, 6(4), 509-525.

Hatcher, T. (2006a). Democratizing the workplace through professionalization of human resource development. International Journal of Training \& Development, 10(1), 67-82.

Hatcher, T. (2006b). An editor's challenge of human resource development. Human Resource Development Quarterly, 17(1), 1-4.

Herr, K. (1999). Unearthing the unspeakable: When teacher research and political agendas collide. Language Arts, $77(1), 10-15$.

Hinsdale, M. A., Lewis, H. M., \& Waller, S. M. (1995). It comes from the people: Community development and local theology. Philadelphia: Temple University Press.

Kemmis, S., \& McTaggart, R. (2000). Participatory action research. In N. K. Denzin \& Y. S. Lincoln (Eds.), Handbook of qualitative research (2nd ed., pp. 567-605). Thousand Oaks, CA: Sage.

Kuchinke, K. P. (1999). Adult development towards what end? A philosophical analysis of the concept as reflected in the research, theory and practice of human resource development. Adult Education Quarterly, 49(4), 148-162.

Marsick, V. J., \& Watkins, K. E. (1997). Case study research methods. In R. A. Swanson \& E. F. Holton, III (Eds.), Human resource development research handbook: Linking research and practice (pp. 138-157). San Francisco: Berrett-Koehler.

Maurer, M. (2006). Dialogic action research. In F. M. Nafukho (Ed.), Academy of Human Resource Development Conference Proceedings (pp. 678-685). Bowling Green, OH: AHRD.

McGuire, D., Cross, C., \& O'Donnell, D. (2005). Why humanistic approaches in HRD won't work. Human Resource Development Quarterly, 16(1), 131-137.

McNiff, J. (2000). Critical theoretical research. In J. McNiff (Ed.), Action research in organisations (pp. 177-190). London: Routledge.

Merrifield, J. (1997). Participatory action research: Knowing, learning, doing. RaPAL Bulletin, 32, $23-27$.

Meyerson, D. E., \& Scully, M. A. (1995). Tempered radicalism and politics of ambivalence and change. Organization Science, 6(5), 585-600.

Noffke, S. E. (1994). Action research: Towards the next generation. Educational Action Research, 2(1), 9-21.

Noffke, S. E. (1997a). Professional, personal, and political dimensions of action research. Review of Research in Education, 22, 305-343.

Noffke, S. E. (1997b). Themes and tensions in US action research: Towards historical analysis. In S. Hollingsworth (Ed.), International action research: A casebook for educational reform (pp. 2-16). London: Falmer Press.

Reason, P., \& Bradbury, H. (2001). Preface. In P. Reason \& H. Bradbury (Eds.), Handbook of action research: Participative inquiry and practice (pp. xxiii-xxxi). London: Sage.

Sambrook, S. (2004). A "critical" time for HRD? Journal of European Industrial Training, 28(8/9), 611-624.

Scully, M., \& Segal, A. (2002). Passion with an umbrella: Grassroots activists in the workplace. In M. Lounsbury \& M. J. Ventresca (Eds.), Social structure and organizations revisited (Vol. 19, pp. 125-168). San Diego, CA: Elsevier Science.

Swanson, R. A. (1997). HRD research: Don't go to work without it! In E. F. Holton, III (Ed.), Human resource development research handbook: Linking research and practice (pp. 3-20). San Francisco: Berrett-Koehler.

Swanson, R. A., \& Holton, E. F., III. (2001). Foundations of human resource development (1st ed.). San Francisco: Berrett-Koehler.

Trehan, K. (2004). Who is not sleeping with whom? What's not being talked about in HRD? Journal of European Industrial Training, 28(1), 23-38.

Trehan, K., \& Rigg, C. (2003). Propositions for incorporating a pedagogy of complexity, emotion and power in HRD education. In M. Lee (Ed.), HRD in a complex world (pp. 204-217). New York: Routledge.

Trist, E. L. (1993). Guilty of enthusiasm. In A. G. Bedein (Ed.), Management laureates: A collection of autobiographical essays (pp. 193-221). Greenwich, CT: JAI Press.

Valentin, C. (2006). Researching human resource development: Emergence of a critical approach to HRD enquiry. International Journal of Training \& Development, 10(1), 17-29.

Vince, R. (2003). Towards a critical practice of HRD. In C. H. J. Gilson, I. Grugulis \& H. Willmott (Eds.), Critical Management Studies Conference Proceedings. Hamilton, New Zealand: Waikato Management School.

Whyte, W. F. (1991). Participatory action research. Newbury Park, CA: Sage. 